\title{
Investigation on Productivity Enhancement of a Solar Still with Transparent Polythene Film Cover and Cylindrical Hollow Fins for Heat Storage
}

\author{
Ali Riahi' ${ }^{1}$, Nor Azazi Zakaria ${ }^{1,}$, , Mohamed Hasnain Isa ${ }^{2}$, \\ Mohd Remy Rozainy Mohd Aref Zainol', Balbir Singh Mahinder Singh ${ }^{3}$, \\ Syafiq Shaharuddin', Mohd Fazly Yusof ${ }^{1}$
}

\author{
1 River Engineering and Urban Drainage Research Centre, Universiti Sains Malaysia, 14300 Nibong Tebal, \\ Penang, Malaysia \\ 2 Civil Engineering Programme, Faculty of Engineering, Universiti Teknologi Brunei, Tungku Highway, Gadong \\ BE1410, Brunei Darussalam \\ 3 Fundamental and Applied Sciences Department, Universiti Teknologi PETRONAS, 32610 Bandar Seri Iskandar, \\ Perak, Malaysia \\ * Corresponding author's e-mail: redac01@usm.my
}

\begin{abstract}
This paper discussed the experimental performance of a solar still with cylindrical hollow fins that were integrated to a black painted stainless-steel basin. The cover of the solar still was made of transparent polythene film, while the frame was made of polyvinyl chloride (PVC). Mild steel cylindrical hollow pipes of $0.035 \mathrm{~m}$ diameter were used as fins in the solar still. The performance of this solar still (PSSCHF) was compared with the performance of a conventional solar still (PSS1) which was made of similar fabrication materials, but without using fins in its basin. Each solar still basin contained water with the depth of $1 \mathrm{~cm}$ that was collected from a pond located at the Universiti Sains Malaysia (USM) campus. Both PSSCHF and PSS1 solar stills were exposed to similar climatic conditions within the same locality at USM during the experiments. The purpose of using the fins in the basin of PSSCHF was to absorb more heat from solar irradiance. The PSSCHF attained a maximum productivity of $4.49 \mathrm{l} / \mathrm{m}^{2} \cdot \mathrm{d}$, whereas the PSS1 obtained a maximum water production of $3.97 \mathrm{l} / \mathrm{m}^{2} \cdot \mathrm{d}$. The quality of fresh water produced from the solar stills met the World Health Organization potable water standards.
\end{abstract}

Keywords: cylindrical hollow fins, solar still, polythene film, potable water production

\section{INTRODUCTION}

People around the world living in remote, arid, rural and coastal areas of many developing countries are facing the problem of drinking water scarcity. Their daily water supply comes from natural water resources such as wells, rivers, lakes and ponds, which are at times contaminated [Taamneh and Taamneh, 2010; Dev and Tiwari, 2011]. The conventional water treatment plants are expensive to build, centralized and are usually far away from these remote areas. Thus, a lowcost treatment technology such as solar desalination (using solar distillation stills) is deemed appropriate for obtaining potable water [Ahsan et al., 2014; Jasrotia et al., 2012; Riahi et al., 2015; Riahi et al., 2018; Velmurugan et al., 2008]. The solar stills that are exposed to the Sun directly, are known as passive solar stills [Dwivedi and Tiwari, 2010]. These solar stills can treat seawater, groundwater, lake water, pond water and industrial effluents [Ahsan et al., 2014; Jasrotia et al., 2012; Riahi et al., 2015; Riahi et al., 2018; Velmurugan et al., 2008] in order to provide safe potable water that meets the WHO drinking water standards.

Several passive solar distillation stills were constructed and their performances in terms of 
productivity enhancement using different cover and basin heat absorbing materials were investigated with different water depths in the basin. A trapezoidal shape glass cover solar still with a combination of fins, sand and sponge as heat storage materials in the basin was fabricated and tested in India. It was exposed to an average solar irradiance of $508.9 \mathrm{~W} / \mathrm{m}^{2}$ [Velmurugan et al., 2008] and the productivity was found to increase up to $2.54 \mathrm{l} / \mathrm{m}^{2} \cdot \mathrm{d}$ with the yield enhanced by $53 \%$ as compared a conventional solar still.

A triangular shape solar still with stainless steel basin covered by glass was fabricated in Jordan [Akash et al., 1998]. The heat storing materials viz., black ink, black rubber and black dye were tested in the solar still basin with water depth of $4 \mathrm{~cm}$. The water production of solar stills improved up to $3.31,3.50$ and $3.851 / \mathrm{m}^{2} \cdot \mathrm{d}$ using black rubber mat, black ink and black dye in the basin, respectively, compared with the conventional still with the output of $2.401 / \mathrm{m}^{2} \cdot \mathrm{d}$ [Akash et al., 1998].

Yellow and black sponge cubes, black coal and black steel were used as heat absorbing materials in the basin of a trapezoidal shape solar still and their performances were compared in Jordan [Abu-Hijleh and Rababa'h, 2003]. The solar still using yellow sponge cubes in the basin obtained higher yield than the solar stills with other heat absorbing materials.

Suspended aluminum and galvanized iron floating plates were used in the basins of two trapezoidal shape glass cover solar stills and productivities of 3.70 and $3.10 \mathrm{~L} / \mathrm{m}^{2} \cdot \mathrm{d}$, respectively, were obtained in India [Panchal et al., 2017]. On the other hand, the conventional still achieved the productivity of only $2.54 \mathrm{~L} / \mathrm{m}^{2} \cdot \mathrm{d}$.

The performances of two similar trapezoidal shape glass cover solar stills with square and circular hollow fins covered with wick materials as heat storing materials in the basins with water depths of 1,2, 3 and $4 \mathrm{~cm}$ were inspected in India [Rajaseenivasan and Srithar, 2016]. The solar stills were exposed to an average solar irradiance of $623 \mathrm{~W} / \mathrm{m}^{2}$, and it was shown that the use of $1 \mathrm{~cm}$ water depth in the basin was more productive than using other basin water depths. The productivity of square finned solar still with wick material increased by $43.98 \%$ and achieved the highest yield of $4.55 \mathrm{~kg} / \mathrm{m}^{2} \cdot \mathrm{d}$, as compared to the conventional and circular finned solar still.

The performances of two triangular shape glass cover solar stills with circular and square hollow fins in the basin were investigated with different water depths of 1, 2 and $3 \mathrm{~cm}$ in India [Jani and Modi, 2019]. The water depth of $1 \mathrm{~cm}$ was shown to be more productive for both stills and the productivity increased up to $1.4917 \mathrm{~kg} / \mathrm{m}^{2} \cdot \mathrm{d}$ by using cylindrical hollow fins in the solar still basin, as compared to the square finned solar still that produced yield of $0.9672 \mathrm{~kg} / \mathrm{m}^{2} \cdot \mathrm{d}$.

The performances of black cotton cloth, Jute cloth, clay pots, cotton pieces and mild steel pieces as heat absorbing materials in single and dual basin solar stills were evaluated in India [Rajaseenivasan et al., 2013] which revealed that the application of mild steel pieces in a dual basin solar still was more effective and increased the water production up to $5.68 \mathrm{l} / \mathrm{m}^{2} \cdot \mathrm{d}$.

A concave shaped wick was applied as a basin heat absorber in a pyramid shaped glass cover solar still in Egypt [Kabeel, 2009]. The solar still achieved a yield of $4.10 \mathrm{l} / \mathrm{m}^{2} \cdot \mathrm{d}$. Several glass cover passive solar stills with black painted troughs as basin were also fabricated and evaluated in Saudi Arabia [Al-Garni, 2012], Egypt [Kabeel et al., 2012] and Malaysia [Sapari et al., 2014] and each of them obtained a different maximum water production of $2.5,3.58$ and $2.26 \mathrm{~kg} / \mathrm{m}^{2} \cdot \mathrm{d}$, respectively.

The investigations on passive solar stills with low-cost transparent cover materials and different heat absorbing materials in the basin were conducted in India [Phadatare and Verma, 2007] and Malaysia [Ahsan et al., 2014; Riahi et al., 2015 and Riahi et al., 2018]. A trapezoidal solar still using a Perspex sheet as cover, frame and basin material was constructed and tested using different basin water depths from $2 \mathrm{~cm}$ to $10 \mathrm{~cm}$ in India [Phadatare and Verma, 2007]. The maximum productivity of $2.1 \mathrm{l} / \mathrm{m}^{2} \cdot \mathrm{d}$ was attained using $2 \mathrm{~cm}$ basin water depth.

A passive triangular solar still (TrSS) was fabricated using a cover layer of polythene film and black painted Perspex sheet basin in Malaysia [Ahsan et al., 2014]. Its performance was investigated using water depths of 1.5 and $3 \mathrm{~cm}$ and it showed that the higher yield of $1.55 \mathrm{~kg} / \mathrm{m}^{2} \cdot \mathrm{d}$ was attained using the lower water depth.

The performance of three double slope passive solar stills with various heat storage materials in the basin was investigated in Malaysia [Riahi et al., 2015]. Each solar still with a tilt angle of $60^{\circ}$ covered with a low-cost transparent polythene film had a frame made of PVC pipes and a basin made of stainless steel trough. Each still 
basin was fed with water to the depth of $3 \mathrm{~cm}$. The solar still with black painted stainless steel basin achieved greater daily yield of $2.227 \mathrm{1} / \mathrm{m}^{2}$ compared to the other two solar stills with the productivities of 1.860 and $1.106 \mathrm{1} / \mathrm{m}^{2}$ with black soil in the still trough and only stainless steel trough without additional energy storage material, respectively [Riahi et al., 2015].

A comparative experimental work was conducted with two passive dual slope solar stills using glass (GSS) and polythene film (PSS) as cover materials in Malaysia [Riahi et al., 2018]. A water depth of $3 \mathrm{~cm}$ was applied in each still basin. PSS and GSS produced the maximum experimental productivity of 3.07 and $3.22 \mathrm{~L} / \mathrm{m}^{2} \cdot \mathrm{d}$ respectively, which showed only a marginally (up to 5\%) higher water production from GSS. However, the PSS fabrication cost was 5 times lower than the cost of GSS. Therefore, PSS was proposed to be applied in the rural regions for cost-effective drinking water production [Riahi et al., 2018].

The performance of two passive basin type solar stills was investigated in Semnan, Iran. One of the solar stills had a pump to soak the enclosure walls, while the other still was a conventional type without integration to a pump [Heydari and Rahbar, 2016]. The rate of water productivity was enhanced by $75 \%$ using the former solar still.

This work investigated the productivity of two passive dual slope solar stills with black painted stainless-steel basins covered with transparent layers of low-cost polythene film; each having basin water depth of $1 \mathrm{~cm}$. The first solar still was named PSS1 and the second solar still which was named PSSCHF had additional 28 black painted mild steel cylindrical hollow fins that acted as an additional heat absorber and storage system. The novelty of this investigation is related to the use of low-cost polythene film layer and cylindrical hollow fins as cover and heat storing material, respectively, in the basin of PSSCHF. The study also compared the water productivity of the two solar stills.

\section{EXPERIMENTAL SET-UP}

Two triangular passive solar stills of identical size, shape and materials were fabricated for this work. A transparent polythene film layer and PVC pipes were utilized as the cover and frame of each solar still, respectively. The two solar stills in this work were fabricated using cost-effective cover materials, compared to the solar still with glass cover (GSS) [Riahi et al., 2018]. These solar stills are lighter than GSS [Riahi et al., 2018], which makes them portable and facilitates transportation to remote locations. The PVC pipes and polythene films used in these solar stills are durable and can last up to 5 years [Ahsan et al., 2013] as compared to the vinyl chloride sheets with durability of 2 years [Ahsan et al., 2012]. Stainless steel was chosen as the trough material to prevent corrosion due to the contact with water and vapours in the still [Eng et al., 2010]. Each solar still trough was painted black to absorb more solar radiation. The trough dimensions were $50 \mathrm{~cm}$ length, $30 \mathrm{~cm}$ width and $8 \mathrm{~cm}$ depth; yielding a basin volume of $12 \mathrm{~L}$. The first solar still with water depth of $1 \mathrm{~cm}$ in its basin was named PSS1. The second solar still, PSSCHF, had additionally 28 black painted mild steel cylindrical hollow fins in the basin to absorb more heat from solar irradiation (Figure 1). Each fin was $3.5 \mathrm{~cm}$ in diameter and $7.5 \mathrm{~cm}$ tall. They were placed in the basin of the PSSCHF with separation distance of $7.5 \mathrm{~cm}$ centre to centre. The area of each solar still was $0.30 \mathrm{~m}^{2}$ (Figure 2). Previous reports have shown increased solar still productivity at lower depth of water in the basin [Ahsan et al., 2014; Rajaseenivasan and Srithar, 2016 and Phadatare and Verma, 2007]. Hence, each solar still basin in this work was fed with $1 \mathrm{~cm}$ of water, which was collected from a typical natural pond at the Universiti Sains Malaysia (USM) engineering campus. The performance of PSS1 was compared with that of PSSCHF (Figures 2 and 3).

The experiments were conducted for a duration of 3 days at the USM engineering campus to evaluate the performances of PSS1 and PSSCHF. The two solar stills were exposed to similar outdoor climatic conditions (Figure 3 ). The total fabrication costs of PSS1 and PSSCHF were RM 82.50 or USD 20.12 and RM 87.50 or USD 21.34, respectively (Table 1 [Riahi et al., 2015]). The difference between the cost of PSS1 and PSSCHF reflects the cost of cylindrical hollow fins. A digital meter was used in order to measure the temperatures of basin water, inner cover of solar stills and ambient air hourly. The intensity of solar radiation in the USM campus was measured every 15 minutes with the use of a pyranometer. Table 2 shows the different instruments with their models, accuracies, range and percentage errors used to measure the intensity of solar radiation, water production and temperature. Vapours were 
(a)

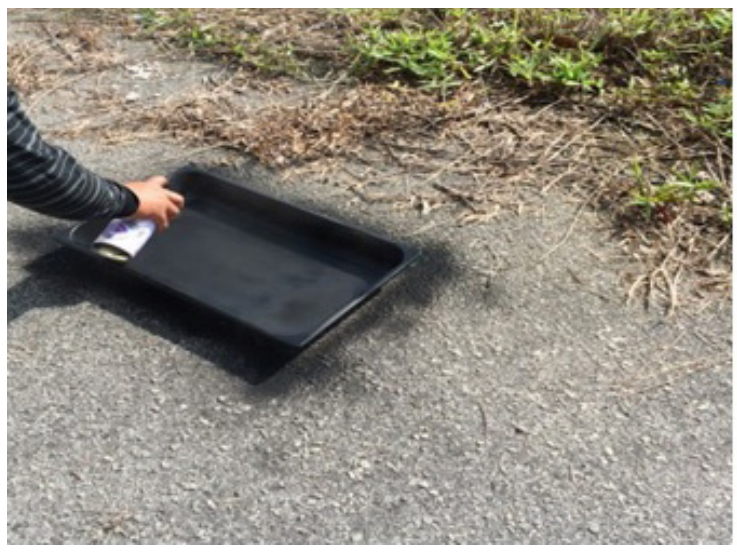

(b)

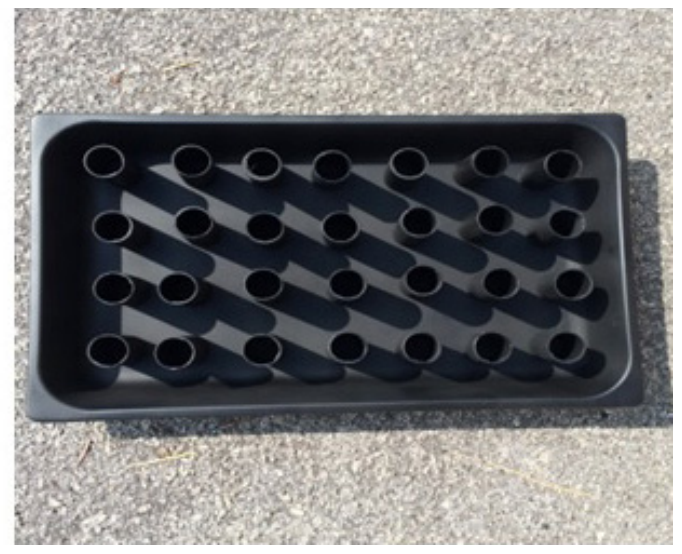

Figure 1. Photographs of the black painted stainless steel basin of PSS1 (a) and the cylindrical hollow fins embedded in the basin of the solar still, PSSCHF (b)

(a)

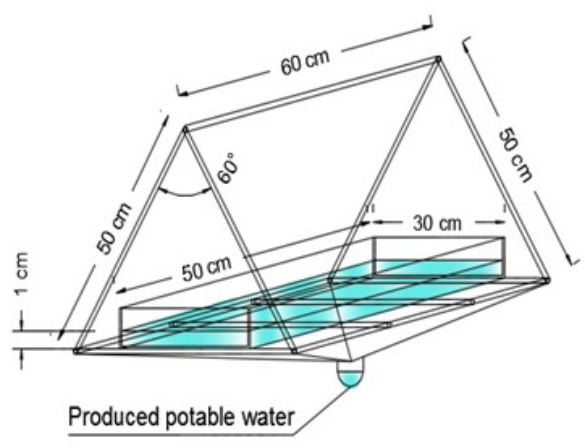

(b)

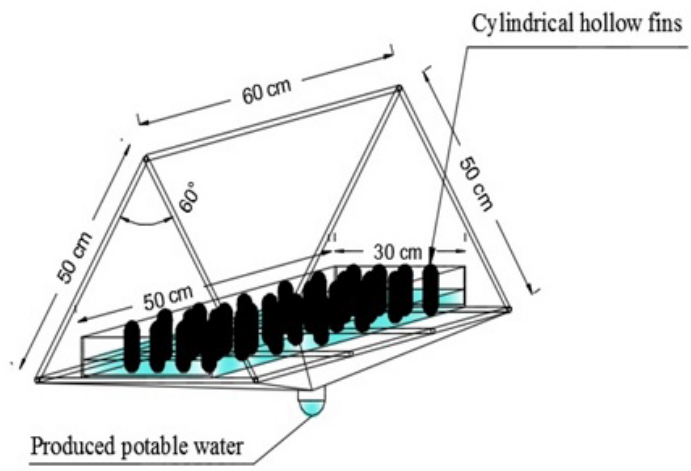

Figure 2. Sketches of the solar still 1, PSS1 (a) and solar still 2, PSSCHF (b)

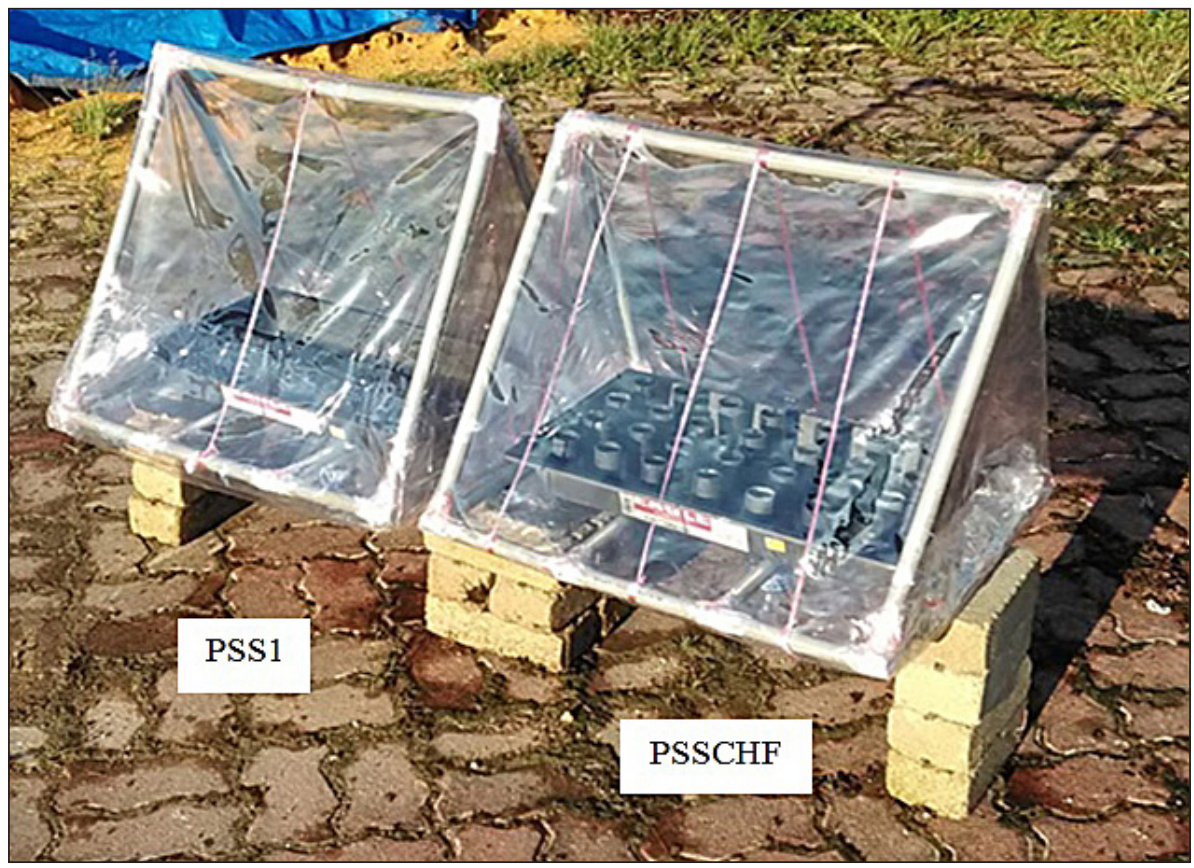

Figure 3. Photograph of the two solar stills, PSS1 and PSSCHF in an open field 
Table 1. Fabrication cost of triangular shape solar still (PSS1) having the black painted stainless steel basin and covered with a polythene film layer [Riahi et al., 2015]

\begin{tabular}{|c|c|c|c|}
\hline Items & Quantity & Unit cost (RM) & Cost (RM) \\
\hline Polythene film cover ( $0.15 \mathrm{~mm}$ thickness) & $1.2 \mathrm{~m}^{2}$ & RM $1.80 / \mathrm{m}^{2}$ & 2.20 \\
\hline PVC pipe frame (15 mm diameter) & $4.8 \mathrm{~m}$ & RM $6.00 / \mathrm{m}$ & 28.20 \\
\hline Stainless steel tray & 1 & 40.00 & 40.00 \\
\hline Plastic rope & $30 \mathrm{~m}$ & RM 12.00/roll & 3.60 \\
\hline Transparent tape & 1 & 2.50 & 2.50 \\
\hline Flat black spray & 1 & 6.00 & 6.00 \\
\hline Total cost & & & 82.50 \\
\hline
\end{tabular}

Note: USD $1 \approx$ RM 4.10

Table 2. Measuring instruments with their model, accuracy, range and percentage errors

\begin{tabular}{|l|c|c|c|c|}
\hline \multicolumn{1}{|c|}{ Instruments } & Model & Accuracy & Range & \% Error \\
\hline Digital multimeter & EM382 & $\pm 1^{\circ} \mathrm{C}$ & 0 to $100{ }^{\circ} \mathrm{C}$ & 1 \\
\hline Pyranometer & Seba Hydrometrie & $\pm 1 \mathrm{~W} / \mathrm{m}^{2}$ & 0 to $3000 \mathrm{~W} / \mathrm{m}^{2}$ & 0.5 \\
\hline Measuring Cylinder & & $\pm 0.5 \mathrm{ml}$ & 0 to $50 \mathrm{ml}$ & 0.5 \\
\hline
\end{tabular}

condensed at the inner side of the PSS1 and PSSCHF transparent covers. The condensed vapours were collected at the bottom of the cover of each solar still. A measuring cylinder was used to measure the amount of condensed water collected. Figure 4 shows the photograph of the collected water from a pond in the USM campus (a) and the produced water from solar stills, PSS1 (b) and PSSCHF (c).

\section{RESULTS AND DISCUSSION}

Table 3 shows the variations of average solar radiation intensity $\left(\mathrm{I}_{\mathrm{s}}\right)$, average temperatures of water $\left(\mathrm{T}_{\mathrm{w}}\right)$, inner cover of the two solar stills $\left(\mathrm{T}_{\text {ic }}\right)$ and ambient air $\left(\mathrm{T}_{\mathrm{a}}\right)$ and cumulative productivities $\left(M_{c}\right)$ of the solar stills, PSS1 and PSSCHF, from 8 am to $6 \mathrm{pm}$ for three typical days, which were the $27^{\text {th }}$ March, and $2^{\text {nd }}$ and $4^{\text {th }}$ April 2019. It was shown that with the rise in the average solar radiation intensity, the average temperature of water and cumulative water production enhanced for each solar still (Table 3 ). The greatest average solar radiation intensity was recorded on $2^{\text {nd }}$ April 2019 with the rate of $678.76 \mathrm{~W} / \mathrm{m}^{2}$, which caused the average temperatures of water and inner cover, and cumulative productivities of PSSCHF and PSS1 to achieve the following values: 49.73

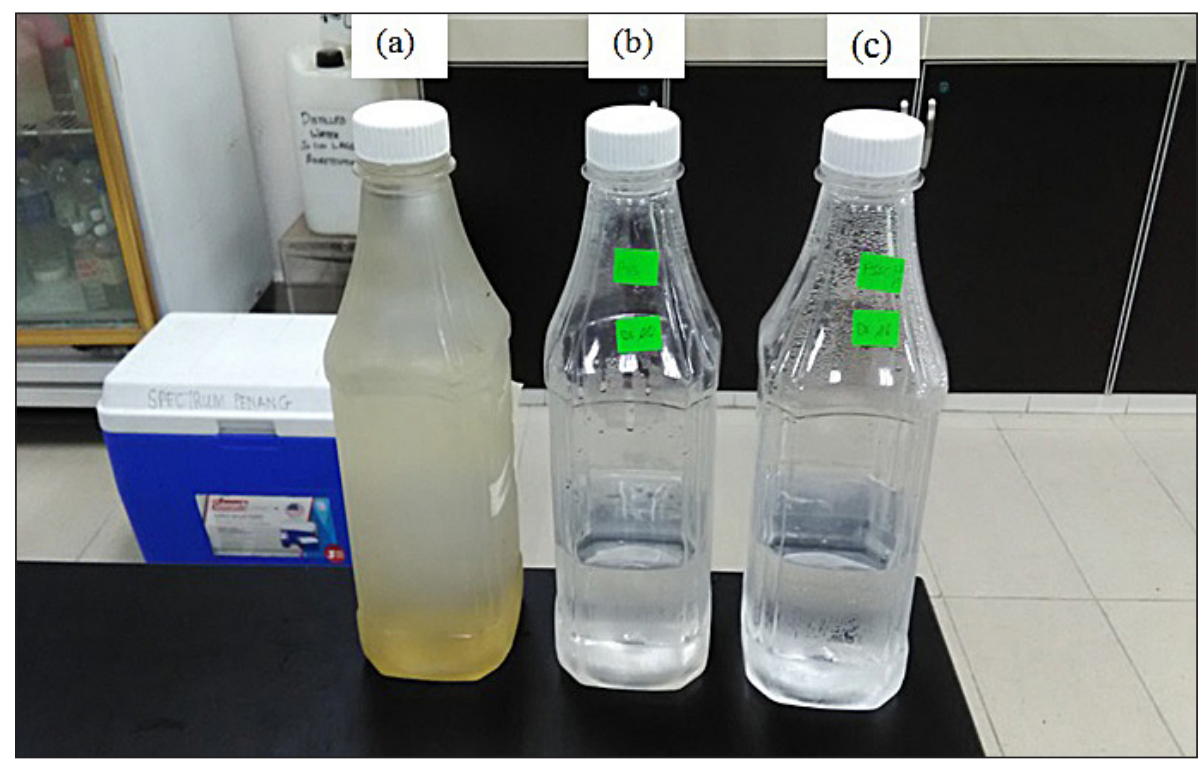

Figure 4. Photograph of the collected pond water (a), produced water by solar stills, PSS1 (b) and PSSCHF (c) 
Table 3. Average $I_{s}, T_{a}, T_{w}, T_{i c}$ and $M_{c}$ from 8 am to $6 \mathrm{pm}$ for PSS1 and PSSCHF for three experimental days

\begin{tabular}{|c|c|c|c|c|c|c|}
\hline Date & $\underset{\left.\mathrm{m}^{2}\right)}{\text { Average }} \mathrm{I}_{\mathrm{s}}(\mathrm{W} /$ & $\begin{array}{c}\text { Average } T_{a} \\
\left({ }^{\circ} \mathrm{C}\right)\end{array}$ & Solar still & $\begin{array}{c}\text { Average } T_{w} \\
\left({ }^{\circ} \mathrm{C}\right)\end{array}$ & $\begin{array}{c}\text { Average } T_{\text {ic }} \\
\left({ }^{\circ} \mathrm{C}\right)\end{array}$ & $\begin{array}{c}M_{c} \\
\left(L / m^{2} . d\right)\end{array}$ \\
\hline \multirow{2}{*}{ 27.03.2019 } & \multirow{2}{*}{527.71} & \multirow{2}{*}{31.09} & PSS1 & 44.81 & 38.18 & 2.89 \\
\hline & & & PSSCHF & 46.64 & 40.00 & 3.36 \\
\hline \multirow{2}{*}{02.04 .2019} & \multirow{2}{*}{678.76} & \multirow{2}{*}{32.18} & PSS1 & 48.27 & 41.18 & 3.97 \\
\hline & & & PSSCHF & 49.73 & 42.00 & 4.49 \\
\hline \multirow{2}{*}{04.04 .2019} & \multirow{2}{*}{630.91} & \multirow{2}{*}{31.55} & PSS1 & 46.91 & 40.55 & 3.71 \\
\hline & & & PSSCHF & 48.46 & 41.27 & 4.09 \\
\hline
\end{tabular}

and $48.27{ }^{\circ} \mathrm{C}, 42.00$ and $41.18{ }^{\circ} \mathrm{C}, 4.49$ and $3.97 \mathrm{l} / \mathrm{m}^{2} \cdot \mathrm{d}$, respectively. Table 3 also shows that the average values of water and inner cover temperatures, and cumulative productivities of PSSCHF were always greater than the corresponding values of PSS1 during those three days. This is attributed to the use of the added heat storage materials viz., mild steel cylindrical hollow fins in the basin of PSSCHF.

\section{Effect of intensity of solar radiation on the temperatures of water and inner cover of solar stills, ambient air temperature and hourly productivity}

The solar radiation intensity (Is) variations on a typical day from 8 am to $6 \mathrm{pm}$ on the $2^{\text {nd }}$ April 2019 are shown in Figure 5. The hourly variations of the temperatures of water and inner cover of PSS 1 and PSSCHF, respectively, versus the hourly yield of the two solar stills on $2^{\text {nd }}$ April 2019 are shown in Figures 6 and 7. The highest $\mathrm{T}_{\mathrm{w} 1}, \mathrm{~T}_{\mathrm{w} 2}, \mathrm{~T}_{\mathrm{ic1}}, \mathrm{T}_{\mathrm{ic} 2}$ and $\mathrm{T}_{\mathrm{a}}$ values of $56,57,47,48$ and $36^{\circ} \mathrm{C}$, respectively, were recorded at 2:00 $\mathrm{pm}$, once the solar radiation intensity reached a peak rate of $1306 \mathrm{~W} / \mathrm{m}^{2}$. The rise and fall of the temperatures of water, inner cover of the solar stills and ambient air corresponded to the growth and decline in the intensity of solar radiation over the day (Figures 5-7). These results conform to other reported studies [Ahsan et al., 2014; Riahi et al., 2015; Riahi et al., 2018].

Figures 5-7 demonstrate the hourly water production of both solar stills corresponding to the solar radiation intensity and water temperatures. It was observed that the highest evaporation during the experiment occurred based on the highest water temperature of both solar stills at $2: 00 \mathrm{pm}$ corresponding to the growth in the solar radiation intensity from $1231 \mathrm{~W} / \mathrm{m}^{2}$ at $1: 00 \mathrm{pm}$ to the peak value of $1306 \mathrm{~W} / \mathrm{m}^{2}$ at $2: 00 \mathrm{pm}$ (Figures 5-7). The highest hourly water production of the solar stills was attained at 3:00 pm, once the solar radiation intensity and temperature of basin water had dropped from 2:00 to 3:00 pm. It showed that the highest hourly condensation was experienced at 3:00 pm within a time lag of 1 hour from the peak values of solar radiation intensity and water temperature. This trend has

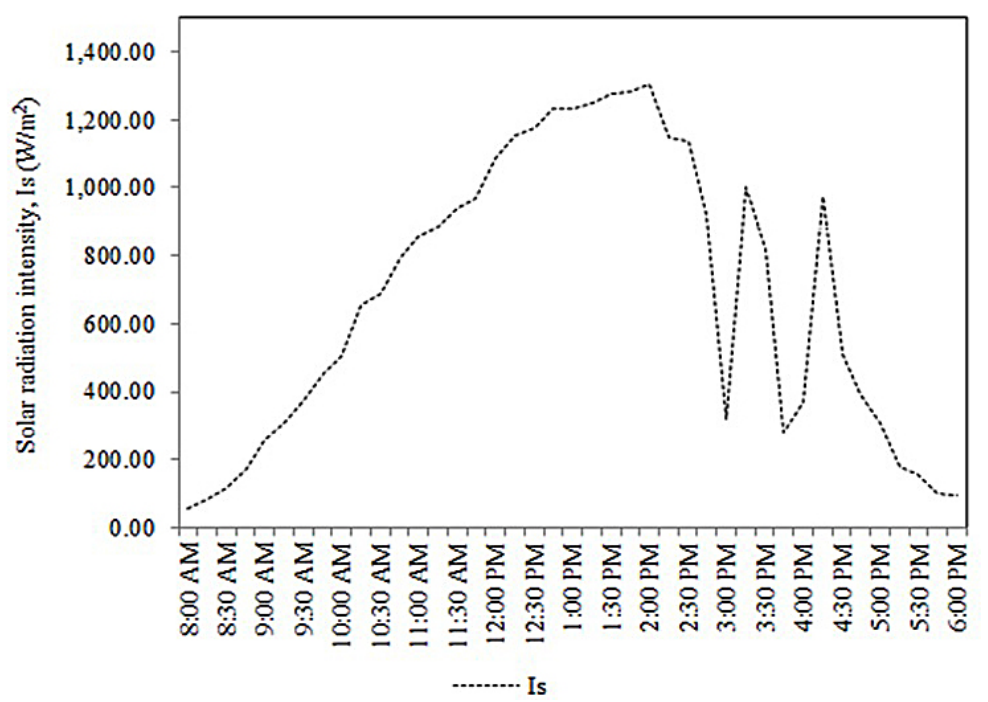

Figure 5. Variations of solar radiation intensity (Is) from 8 am to 6 pm on a typical day on 2nd April 2019 


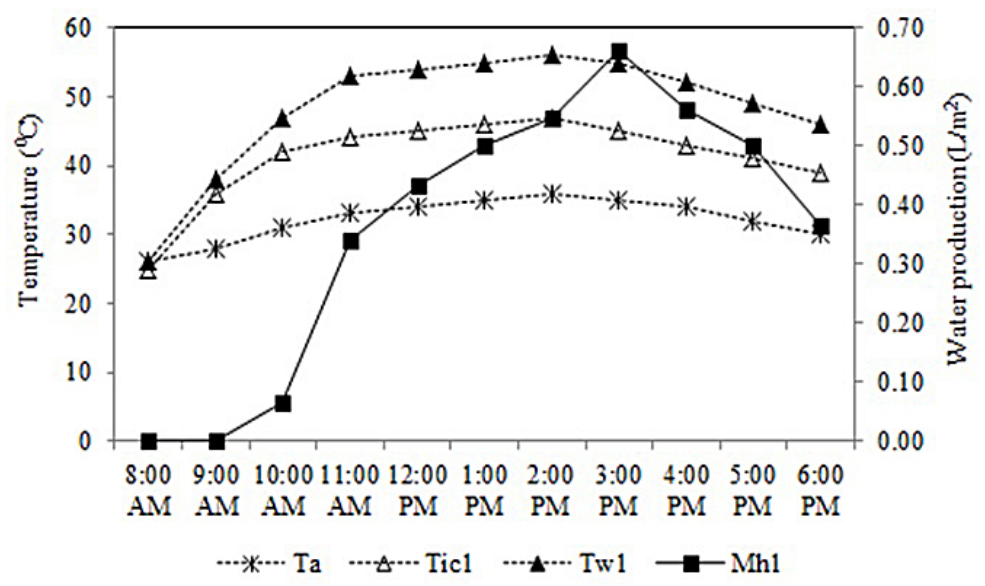

Figure 6. Variations of temperatures of water and inner cover of PSS1 and hourly water production of PSS1, respectively, from 8 am to $6 \mathrm{pm}$ on a typical day on 2nd April 2019

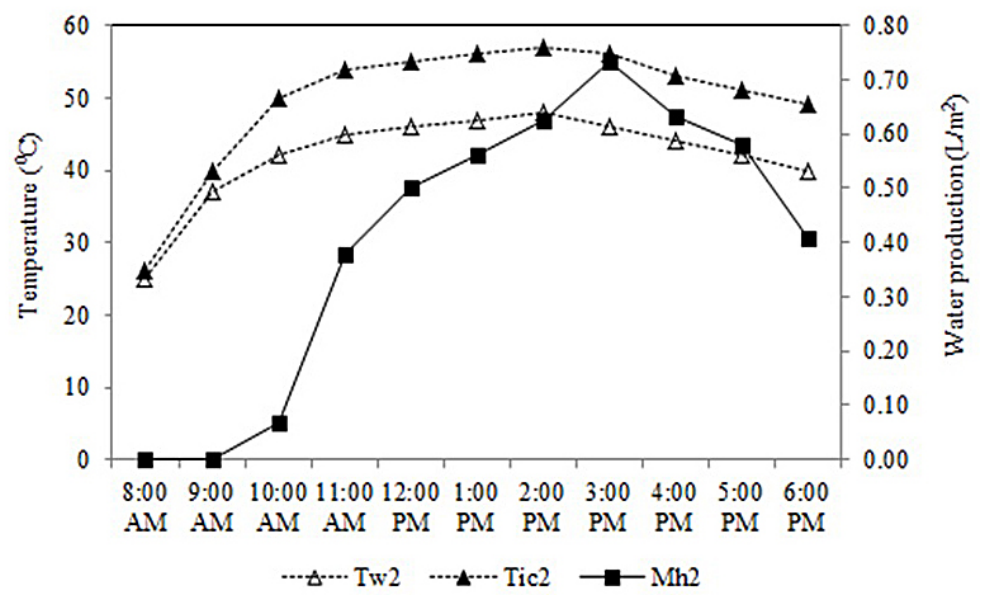

Figure 7. Variations of temperatures of water and inner cover of PSSCHF and hourly water production of PSSCHF, respectively, from 8 am to 6 pm on a typical day on 2nd April 2019

also been reported in some earlier works [Ahsan et al., 2014; Riahi et al., 2015; Riahi et al., 2018; El-Sebaii, 2004; Zurigat, 2004; A1-Hayeka and Badran, 2004; Riahi et al., 2016]. It was also observed from Figures 5-7 that the hourly water production of PSSCHF was always higher than that of PSS1 during the experiment due to the use of additional cylindrical hollow fins in the basin of PSSCHF. The fins performed as heat storage basin material, absorbed more heat from solar irradiance, augmented the water temperature and enhanced the amount of water evaporation from the solar stills.

\section{Cumulative water production}

The maximum values of cumulative productivity for PSS1 $\left(\mathrm{M}_{\mathrm{c} 1}\right)$ and PSSCHF $\left(\mathrm{M}_{\mathrm{c} 2}\right)$ on a typical day on $2^{\text {nd }}$ April 2019 are shown in Figure 8 and Table 3. PSS1 and PSSCHF produced potable water with the maximum total amount of 3.97 and $4.491 / \mathrm{m}^{2}$ respectively during the experiment respectively. The effect of using the cylindrical hollow fins is evident (Table 3). PSSCHF produced a greater amount of water, as compared to the other solar stills previously examined in Malaysia [Ahsan et al., 2014; Riahi et al., 2018; Sapari et al., 2014], India [Velmurugan et al., 2008; Phadatare and Verma, 2007], Egypt [Kabeel, 2009; Kabeel et al., 2012], Jordan [Akash et al., 1998] and Saudi Arabia [Al-Garni, 2012] with the cumulative productivity of $1.55,3.22,2.26,2.54,2.1,4.10$, $3.58,3.85$ and $2.50 \mathrm{~L} / \mathrm{m}^{2}$.d respectively. PSS1 with $1 \mathrm{~cm}$ basin water depth, in this work, also produced higher amount of water compared to the other previously reported solar stills [Ahsan et al., 2014; Riahi et al., 2018; Velmurugan et al., 2008; Kabeel et al., 2012; Sapari et al., 2014 and Phadatare and Verma, 2007]. 


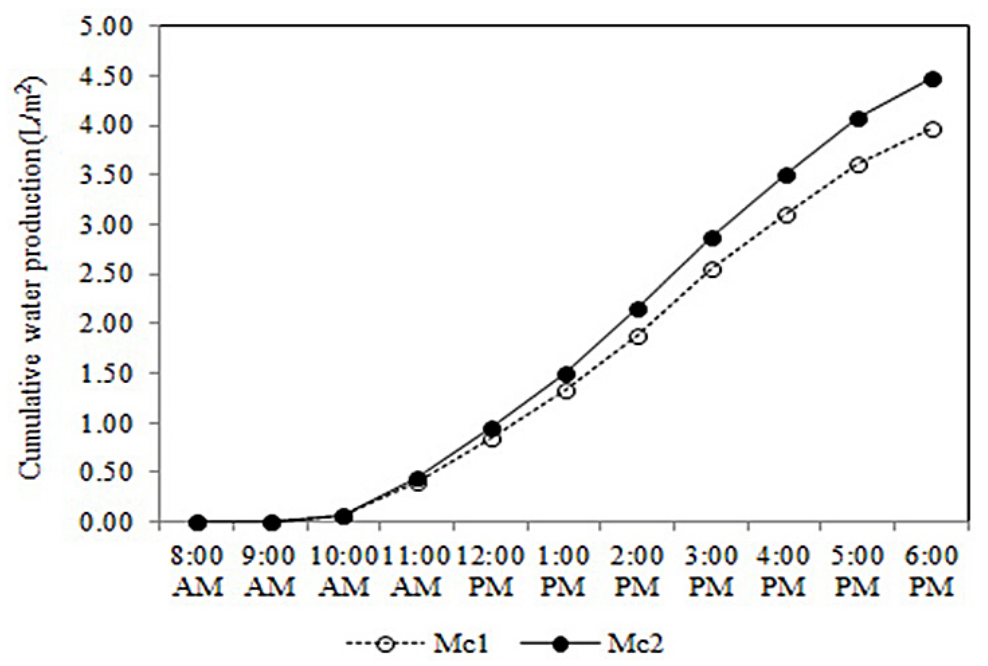

Figure 8. Values of cumulative water production of PSS1 (Mc1) and PSSCHF (Mc2) from 8 am to 6 pm on a typical day on 2nd April 2019

Table 4. Performance evaluation of the solar stills used for treatment of a typical pond water in the USM campus

\begin{tabular}{|l|c|c|c|}
\hline \multicolumn{1}{|c|}{ Water quality parameter } & Pond water (average) & $\begin{array}{c}\text { Generated water by solar } \\
\text { stills (average) }\end{array}$ & $\begin{array}{c}\text { WHO standards } \\
{[\text { WHO, 2008, 2011] }}\end{array}$ \\
\hline $\mathrm{pH}$ & 8.12 & 7.56 & $6.5-8.0$ \\
\hline Total dissolved solids $(\mathrm{mg} / \mathrm{l})$ & 267 & 85.44 & $<600$ \\
\hline Salinity $(\mathrm{ppt})$ & 0.07 & 0.025 & $<0.25$ \\
\hline Free ammonia, $\mathrm{NH}_{3}(\mathrm{mg} / \mathrm{l})$ & 0.07 & 0.035 & $<1.5$ \\
\hline Nitrate $(\mathrm{mg} / \mathrm{l})$ & 0.75 & 0.06 & $<50$ \\
\hline Nitrite $(\mathrm{mg} / \mathrm{l})$ & 0.004 & 0.001 & $<0.05$ \\
\hline Turbidity $(\mathrm{NTU})$ & 4.22 & 0.53 & $<5$ \\
\hline Electrical conductivity $(\mu \mathrm{SS} / \mathrm{cm})$ & 178.6 & 57.25 & $<250$ \\
\hline Color $($ Hazen) & 6 & 0 & $<5$ \\
\hline Total coliform $(\mathrm{CFU} / 100 \mathrm{ml})$ & 179 & 8 & $<100 / 100 \mathrm{ml}$ \\
Faecal coliform $(\mathrm{CFU} / 100 \mathrm{ml})$ & 51 & 3 & $<10 / 100 \mathrm{ml}$ \\
\hline
\end{tabular}

\section{Water quality analysis}

The average quality parameters of the water generated by PSS1 and PSSCHF from a typical pond and the standards of WHO drinking water guidelines are shown in Table 4. The values of $\mathrm{pH}$, salinity, total dissolved solids (TDS), nitrate, free ammonia $\left(\mathrm{NH}_{3}\right)$, nitrite, electrical conductivity (EC), turbidity, colour, total coliforms and faecal coliforms reduced from 8.12, $0.07 \mathrm{ppt}, 267 \mathrm{mg} / \mathrm{L}$, $0.75 \mathrm{mg} / 1,0.07 \mathrm{mg} / 1,0.004 \mathrm{mg} / \mathrm{l}, 178.6 \mu \mathrm{S} / \mathrm{cm}$, 4.22 NTU, 6 Hazen, 179/100 $\mathrm{ml}$ and 51/100 ml before treatment to $7.56,0.025 \mathrm{ppt}, 85.44 \mathrm{mg} / \mathrm{l}$, $0.06 \mathrm{mg} / 1,0.035 \mathrm{mg} / 1,0.001 \mathrm{mg} / \mathrm{l}, 57.25 \mu \mathrm{S} / \mathrm{cm}$, $0.53 \mathrm{NTU}, 0$ Hazen, $8 / 100 \mathrm{ml}$ and $3 / 100 \mathrm{ml}$, respectively, after treatment by the solar stills. This indicated that the quality parameters of the generated water in this work were within the permitted ranges of the standards of WHO drinking water guidelines [WHO, 2008, 2011].

\section{CONCLUSIONS}

In this work, the performance of PSS1 and PSSCHF with the basin water depth of $1 \mathrm{~cm}$ was investigated and it can be concluded that PSSCHF obtained a maximum daily water production of $4.49 \mathrm{l} / \mathrm{m}^{2}$, while PSS1 recorded a total daily output of $3.97 \mathrm{1} / \mathrm{m}^{2}$ under similar climatic conditions. In other words, PSSCHF produced 13.1\% higher experimental yield, as compared to PSS1. Therefore, PSSCHF and PSS1 are proposed to be used for generating cost-effective drinking water in the rural areas.

\section{Acknowledgement}

The authors highly appreciate the funding (Grant Code: 304.PREDAC.6315331) provided by Universiti Sains Malaysia (USM) to carry out this work. 


\section{REFERENCES}

1. Abu-Hijleh B., Rababa'h H.M. 2003. Experimental study of a solar still with sponge cubes in basin. Energy Conversion and Management, 44(9), 1411-1418.

2. Ahsan A., Imteaz M., Rahman A., Yusuf B., Fukuhara T. 2012. Design, fabrication and performance analysis of an improved solar still. Desalination, 292, 105-112.

3. Ahsan A., Imteaz M., Thomas U.A., Azmi M., Rahman A., Nik Daud, N.N. 2014. Parameters affecting the performance of a low cost solar still. Applied Energy, 114, 924-930.

4. Ahsan A., Rahman A., Shanableh A., Nik Daud N.N., Mohammed T.A., Mabrouk A.N.A. 2013. Life cycle cost analysis of a sustainable solar water distillation technique. Desalination and Water Treatment, 51(40-42), 1-8.

5. Akash B.A., Mohsen M.S., Osta O., Elayan Y. 1998. Experimental evaluation of a single basin solar still using different absorbing materials. Renewable Energy, 14(1-4), 307-310.

6. Al-Garni A.Z. 2012. Productivity enhancement of solar still using water heater and cooling fan. Journal of Solar Energy Engineering, 134(3), p. 031006.

7. Al-Hayeka I., Badran O.O. 2004. The effect of using different designs of solar stills on water distillation. Desalination, 169(2), 121-127.

8. Dev R., Tiwari G.N. 2011. Characteristic equation of the inverted absorber solar still. Desalination, 269, 67-77.

9. Dwivedi V.K., Tiwari G.N. 2010. Experimental validation of thermal model of a double slope active solar still under natural circulation mode. Desalination, 250(1), 49-55.

10. El-Sebaii A.A. 2004. Effect of wind speed on active and passive solar stills. Energy Conversion and Management, 45(7-8), 1187-1204.

11. Eng N.H., Lim E.W., Lim Y.C. 2010. Focus goal SPM chemistry. Malaysia: Pelangi.

12. Heydari A., Rahbar N. 2016. Energy and life cost analysis of a wet wall solar still with various pump working conditions. Environmental Progress and Sustainable Energy, 36(2), 532-538.

13. Jani H.K., Modi K.V. 2019. Experimental performance evaluation of single basin dual slope solar still with circular and square cross-sectional hollow fins. Solar Energy, 179, 186-194.

14. Jasrotia S., Kansal A., Kishore V.V.N. 2012. Application of solar energy for water supply and sanitation in Arsenic affected rural areas: A study for Kaudikasa village, India. Journal of Cleaner Production, 37, 389-393.

15. Kabeel A.E. 2009. Performance of solar still with a concave wick evaporation surface. Energy, 34(10), 1504-1509.
16. Kabeel A.E., Khalil A., Omara Z.M., Younes M.M. 2012. Theoretical and experimental parametric study of modified stepped solar still. Desalination, 289, 12-20.

17. Panchal H., Patel P., Patel N., Thakkar H. 2017. Performance analysis of solar still with different energy-absorbing materials. International Journal of Ambient Energy, 38(3), 224-228.

18. Phadatare M.K., Verma S.K. 2007. Influence of water depth on internal heat and mass transfer in a plastic solar still. Desalination, 217(1-3), 267-275.

19. Rajaseenivasan T., Elango T., Kalidasa Murugavel K. 2013. Comparative study of double basin and single basin solar stills. Desalination, 309, 27-31.

20. Rajaseenivasan T., Srithar K. 2016. Performance investigation on solar still with circular and square fins in basin with $\mathrm{CO} 2$ mitigation and economic analysis. Desalination, 380, 66-74.

21. Riahi A., Wan Y.K., Mahinder Singh B.S., Isa M.H., Olisa E., Zahari N.A.M. 2016. Sustainable potable water production using a solar still with photovoltaic modules-AC heater. Desalination and Water Treatment, 57(32), 14929-14944.

22. Riahi A., Yusof K.W., Isa M.H., Mahinder Singh B.S., Mustaffa Z., Ahsan A., Ul Mustafa M.R., Sapari N., Zahari N.A.M. 2018. Potable water production using two solar stills having different cover materials and fabrication costs. Environmental Progress and Sustainable Energy, 37 (1), 584-596.

23. Riahi A., Yusof K.W., Mahinder Singh .B.S., Olisa E., Sapari N.B., Isa M.H. 2015. The performance investigation of triangular solar stills having different heat storage materials. International Journal of Energy and Environmental Engineering, 6 (4), 385-391.

24. Sapari N.B., Ahmadan N.A.M., Riahi A., Orji K.U. 2014. The performance of trapezoidal glass cover solar still during monsoon period of tropical environment. Applied Mechanics and Materials, 567, 161-166.

25. Taamneh Y., Taamneh M.M. 2010. Performance of pyramid-shaped solar still: Experimental study. Desalination, 291, 65-68.

26. Velmurugan V., Deenadayalan C.K., Vinod H., Srithar K. 2008. Desalination of effluent using fin type solar still. Energy, 33(11), 1719-1727.

27. World Health Organization. 2008. Guidelines for drinking-water quality. Incorporating the first and second Addenda, third edition. WHO press, Geneva, Switzerland.

28. World Health Organization. 2011. Guidelines for Drinking-Water Quality, fourth edition. WHO press, Geneva, Switzerland.

29. Zurigat Y.H., Abu-Arabi M.K. 2004. Modelling and performance analysis of a regenerative solar desalination unit. Applied Thermal Engineering, 24(7), 1061-1072. 